\title{
Mass mortality of pond-reared Carassius gibelio caused by Myxobolus ampullicapsulatus in China
}

\author{
B. W. Xi ${ }^{1,2}$, J. Xie ${ }^{1,2, *}$, Q. L. Zhou ${ }^{1}$, L. K. Pan ${ }^{1}$, X. P. Ge ${ }^{1}$ \\ ${ }^{1}$ Freshwater Fisheries Research Center, Chinese Academy of Fishery Sciences, 214081 Wuxi, PR China \\ ${ }^{2}$ Wuxi Fishery College, Nanjing Agriculture University, 214081 Wuxi, PR China
}

\begin{abstract}
From June to August 2009, allogynogenetic silver crucian carp Carassius gibelio (Bloch) pond-cultured at the Nanquan Experimental Station, China, were found to be heavily infected with myxosporeans, which caused mortalities ranging from $33 \%(13 / 40)$ to $90 \%(36 / 40)$ in the cages. The pharynxes of infected fish were swollen, nodular, and severely damaged. Based on morphological characters and 18S small subunit ribosomal DNA sequence similarity, the myxosporean was identified as Myxobolus ampullicapsulatus. This is the first report of $M$. ampullicapsulatus causing mass mortality of pond-reared C. gibelio.
\end{abstract}

KEY WORDS: Myxosporea • Crucian carp • Mortality

Resale or republication not permitted without written consent of the publisher

The allogynogenetic silver crucian carp Carassius gibelio (Bloch) has been cultured on a large scale in recent years in China, especially in the middle and lower reaches of the Yangtze River (Wang et al. 2001). The annual production capacity is up to 2 million $t$. In eastern China, Jiangsu Province is a main culture zone, and the culture area of allogynogenetic silver crucian carp is almost 50000 ha. However, since the 1990s, infection with myxosporeans has caused serious losses of local fish stocks.

During our previous field investigation of myxosporeans parasitic to farmed allogynogenetic silver crucian carp from Jiangsu Province, 6 myxosporean species with visible white 'cysts' were found: Thelohanellus wuhanensis Xiao and Chen, 1993, from the skin of 1 yr allogynogenetic silver crucian carp fry; Myxobolus wulii Landsberg and Lom, 1991 (syn., M. guanqiaoensis, Myxosoma magna), from hepatopancreas; M. koi Kudo, 1919, M. pyramidis Chen, 1998, and M. carassii Klokacewa, 1914, from gills; and $M$. ampullicapsulatus Zhao, Sun, Kent, Deng and Whipps, 2008, from pharynx. Among the 6 species, M. ampullicapsulatus caused the most severe mortality on the fish farms. These mortalities occurred annually, typically in the period from July to September. Here, we report for the first time mass mortality of allogynogenetic silver crucian carp due to myxosporidiosis caused by $M$. ampullicapsulatus.

On 15 June 2009, 2400 allogynogenetic silver crucian carp fry (20 to $35 \mathrm{~g}$ ) were bought from Yancheng $\left(32^{\circ} 37^{\prime}\right.$ to $34^{\circ} 28^{\prime} \mathrm{N}, 119^{\circ} 43^{\prime}$ to $\left.120^{\circ} 52^{\prime} \mathrm{E}\right)$, Jiangsu Province, the main area of epidemic myxosporidioses, and reared in 60 net-cages $\left(1 \mathrm{~m}^{3}\right.$, floating in a 0.2 ha pond) separately in the Nanquan Experimental Station of the Freshwater Fisheries Research Center, Chinese Academy of Fishery Sciences (CAFS; $31^{\circ} 25^{\prime} \mathrm{N}, 120^{\circ} 15^{\prime} \mathrm{E}$ ). In the original design, the fish were employed for a nutrition experiment; however, mortality with heavy myxosporean infection in the pharyngeal region was observed on 30 July. Dead fish were examined and recorded daily. Infected fish showed anorexia, lethargy and sluggish swimming, pharynx inflammation, and eyes protruding due to the mechanical pressure of the parasite mass. Pharynxes with heavy infections were swollen, nodular, and severely damaged (Fig. 1). The nodular lesions immediately ruptured, and liquefaction occurred after the fish died. This disease has been referred to as 'throat cancer' at the fish 

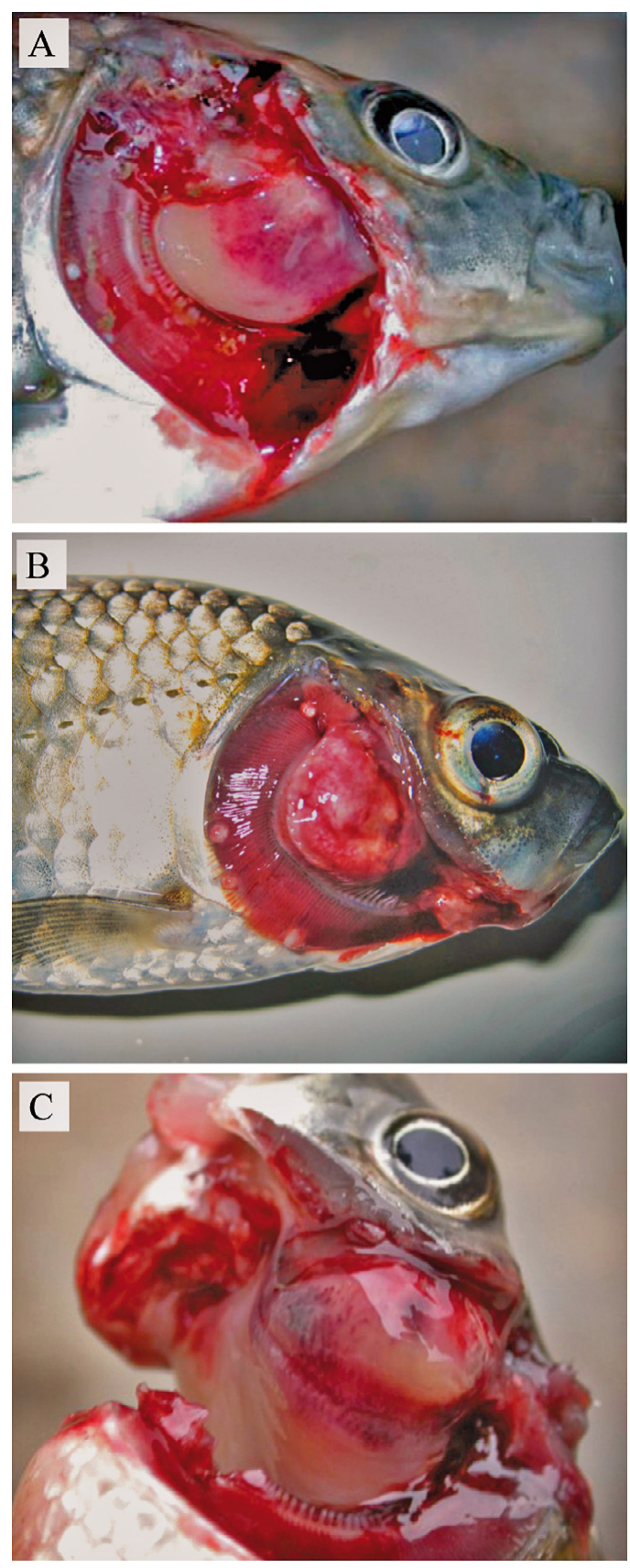

Fig. 1. Myxobolus ampullicapsulatus infecting Carassius gibelio. (A) Inflammation in the pharynx; (B) cyst distorting the gill and blocking respiration; (C) nodule lesion in the pharynx. In (A) and (B), the small white nodules in the gill are M. koi cysts

farms. On 27 August, all fish in the pond were caught and examined. The cumulative mortality in the cages ranged from $33 \%(13 / 40)$ to $90 \%(36 / 40)$.

The nodular lesions in the pharyngeal region were excised and fixed in 10\% neutral buffered formalin and $95 \%$ ethanol. The plasmodia were detected under the orbit and before the epibranchial organs in the
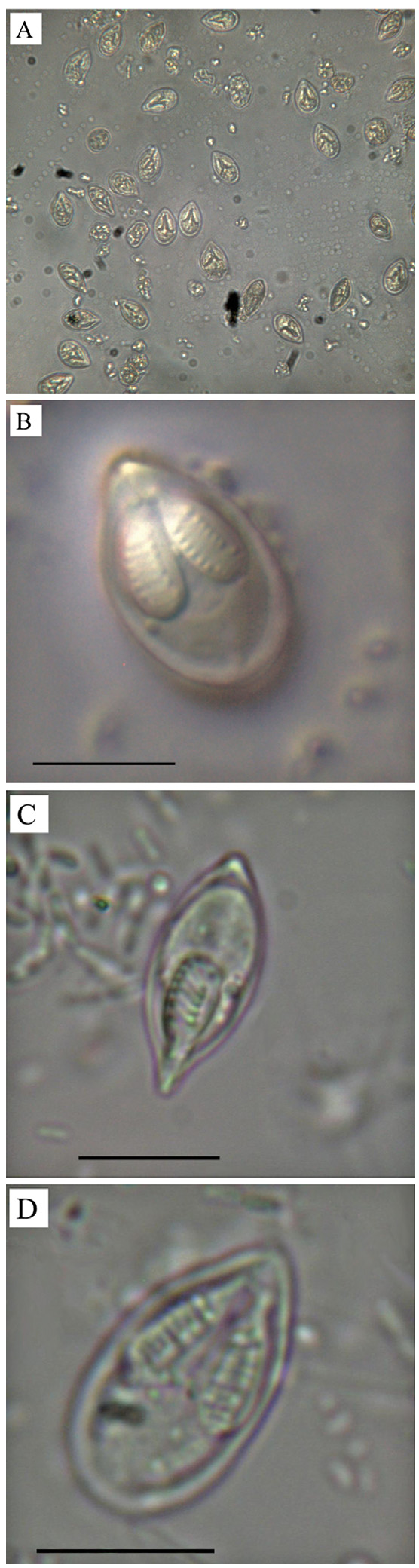

Fig. 2. Myxobolus ampullicapsulatus. Formalin-fixed spores from the pharynx of silver crucian carp. (A) Spores released from plasmodium; (B,D) Front view; (C) sutural view (scale bars $=10 \mu \mathrm{m})$ 
pharyngeal region (Fig. 1). Small parts of formalinfixed tissue were placed on glass slides in physiological saline, mechanically ruptured, and observed under a microscope. Large numbers of Myxobolus spores were seen in the field of view (Fig. 2A). Measurements of spores were taken with an ocular micrometer following the guidelines of Lom \& Arthur (1989). Mature spores (formalin fixed, $\mathrm{n}=20$, Fig. 2B-D) were elongated, pyriform in shape, pointed anteriorly and posteriorly bluntly round in frontal view, and lentoid in sutural view with a straight and narrow sutural ridge 17.9 (16.7-18.5) $\mu \mathrm{m}$ long and 9.1 (8.4-9.6) $\mu \mathrm{m}$ wide. The 2 polar capsules were equal or slightly different in size and occupied about half the length of the spore, measuring 8.8 (8.4-9.6) $\mu \mathrm{m}$ in length and 3.2 (3.03.6) $\mu \mathrm{m}$ in width. A mucous envelope was absent. The spores closely resembled $M$. ampullicapsulatus Zhao, Sun, Kent, Deng and Whipps, 2008, in size and shape, which was first identified from the gills of Carassius auratus auratus (L., 1758) in Chongqing, southwestern China (Zhao et al. 2008). The present spores were similar in size to $M$. wulii, but they clearly differed in the spore length/width and could be distinguished from M. aureatus Ward, 1919, and M. longisporus Nie and Li, 1992, by the distinct spore dimensions (Table 1).

Genomic DNA of Myxobolus from the pharynx of allogynogenetic silver crucian carp were extracted, and a partial 18S (small subunit ribosomal DNA, SSU rDNA) sequence was amplified with the primers ERIB1 and ERIB10 (Barta et al. 1997) following the procedure of Zhang et al. (2010). PCR products were detected on $1.5 \%$ agarose gels, purified with an Agarose Gel DNA Extraction Kit (TaKaRa), and then sequenced directly with an ABI3730xl DNA analyzer (Applied Biosystems). Four $1996 \mathrm{bp}$ fragments of 18S rDNA were successfully amplified. They showed identical sequences and were deposited in the GenBank database under accession no. HM188545. The obtained sequence was compared to similar sequences of described myxozoans identified using a BLAST search for the most related sequences in the NCBI database (Table 2). Pairwise comparisons (p-distance) using the MEGA4.0 software package (Tamura et al. 2007) revealed that the obtained sequence showed high identity $(98.5 \%)$ with the sequence of M. ampullicapsulatus (DQ339482) determined by Zhao et al. (2008), with variations at only 23 sites. The sequence was $\leq 93 \%$ similar to the sequences of $M$. toyamai, $M$. wulii, M. koi, M. longisporus, and others available from GenBank. Although there is some debate as to whether species can be identified based on the level of sequence similarity, 1 to $3 \%$ of intraspecific genetic variation has been demonstrated in many reports (Whipps et al. 2003, Cone et al. 2005, Easy et al. 2005). For example, the18S rDNA sequence of different isolates of $M$. koi from the

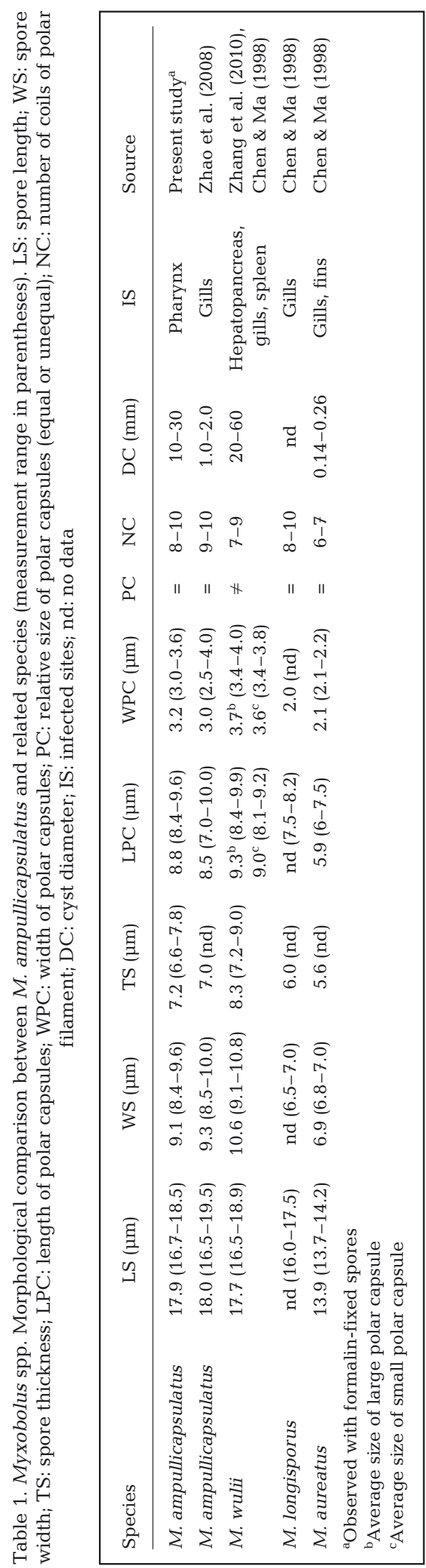


Table 2. Myxobolus spp. Identity of M. ampullicapsulatus small subunit ribosomal DNA (SSU rDNA) sequence as compared to the most related SSU rDNA sequences of Myxobolus available on GenBank. Values are ratios in bp with percentage in parentheses

\begin{tabular}{|lcc|}
\hline Species & $\begin{array}{c}\text { Sequence identity to } \\
\text { M. ampullicapsulatus }\end{array}$ & $\begin{array}{c}\text { GenBank } \\
\text { accession no. }\end{array}$ \\
\hline M. ampullicapsulatus ${ }^{\mathrm{a}}$ & $1554 / 1577(98.5)$ & DQ339482 \\
M. toyamai & $1813 / 1954(92.8)$ & FJ710802 \\
M. koi & $1812 / 1958(92.5)$ & FJ710800 \\
M. longisporus & $1815 / 1964(92.4)$ & AY364637 \\
M. wulii & $1456 / 1579(92.2)$ & EF690300 \\
${ }^{\text {a Sequence determined by Zhao et al. (2008) }}$ & \\
\hline
\end{tabular}

US (FJ841887, Camus \& Griffin 2010) and China (FJ710800, Zhang et al. 2010) showed only 97\% sequence identity (1879/1930). Therefore, based on the similar morphological characters and molecular sequence, the reported Myxobolus is considered to be M. ampullicapsulatus.

The gills, brain, liver, kidney, and spleen of allogynogenetic silver crucian carp reared in this report were also carefully examined with wet mount preparations (Chen \& Ma 1998). No other myxosporean infections were found, except a few cases with Myxobolus koi infection in the gill filament (Fig. 1). Moreover, the dead fish did not show symptoms suggestive of bacterial or viral infections. Therefore, the primary cause for the mortality among the allogynogenetic silver crucian carp was considered the massive parasitism of the pharynx by $M$. ampullicapsulatus, resulting in distortion of the pharynx, blocking fish respiration and feeding.

Myxobolus ampullicapsulatus was originally described from the gills (Zhao et al. 2008), whereas the isolates reported here parasitized a different site. Although host tissue specificity for myxosporeans is generally strict, use of different habitats has also been demonstrated for some other species. For example, $M$. artus has been found from the trunk muscle, intestine, brain, and liver of grass carp (Chen \& Ma 1998), and M. wulii has been found both in the gills and in the hepatopancreas of Carassius auratus (Zhang et al. 2010).

Oral administrations of robenidine, hydrochloride, trichlorfon, levamisole diclazuril, and Chinese herbs (e.g. Stemona, Rhizoma) have been employed by the farms against the myxozoan infection. However, since the annual mortality associated with 'throat-cancer' has persisted in the fish farms, these control measures have not been effective. In early July 2009, almost $2 / 3$ of the allogynogenetic silver crucian carp at a fish farm in Dafeng, Jiangsu, were killed by the 'throat cancer' caused by Myxobolus ampullicapsulatus. Further studies on the life cycle, seasonal dynamics, pathology, and control of M. ampullicapsulatus are desired.

Acknowledgements. We thank L.T. Ye and Y. Chen for help in field sampling. The work was supported by the Special Fund for Basic Scientific Research of the Central Institutes, Freshwater Fisheries Research Center, CAFS (project no. 6115080) and the earmarked fund for the Modern Agro-Industry Technology Research System (NYCYTX-49-18).

\section{LITERATURE CITED}

Barta JR, Martin DS, Liberator PA, Dashkevicz M and others (1997) Phylogenetic relationships among eight Eimeria species infecting domestic fowl inferred using complete small subunit ribosomal DNA sequences. J Parasitol 83: 262-271

Camus AC, Griffin MJ (2010) Molecular characterization and histopathology of Myxobolus koi infecting the gills of a koi, Cyprinus carpio, with an amended morphological description of the agent. J Parasitol 96:116-124

Chen QL, Ma CL (1998) Fauna Sinica Invertebrata, Vol 15. Myxozoa, Myxosporea. Science Press, Beijing

Cone DK, Yang J, Sun G, Easy R (2005) Taxonomy and molecular phylogeny of Myxobolus bilobus n. sp. (Myxozoa) parasitizing Notemigonus crysoleucas (Cyprinidae) in Algonquin Park, Ontario, Canada. Dis Aquat Org 66: $227-232$

> Easy RH, Johnson SC, Cone DK (2005) Morphological and molecular comparison of Myxobolus procerus (Kudo, 1934) and $M$. intramusculi n. sp. (Myxozoa) parasitizing muscles of the trout-perch Percopsis omiscomaycus. Syst Parasitol 61:115-122

Lom J, Arthur JR (1989) A guideline for the preparation of species descriptions in Myxosporea. J Fish Dis 12: 151-156

Tamura K, Dudley J, Nei M, Kumar S (2007) MEGA4: Molecular Evolutionary Genetics Analysis (MEGA) software version 4.0. Mol Biol Evol 24:1596-1599

> Wang GT, Yao WJ, Wang JG, Lu YS (2001) Occurrence of thelohanellosis caused by Thelohanellus wuhanensis (Myxosporea) in juvenile allogynogenetic silver crucian carp, Carassius auratus gibelio (Bloch), with an observation on the efficacy of fumagillin as a therapeutant. J Fish Dis 24:57-60

Whipps CM, Adlard RD, Bryant MS, Lester RJ, Findlay V, Kent ML (2003) First report of three Kudoa species from eastern Australia: Kudoa thyrsites from mahi mahi (Coryphaena hippurus), Kudoa amamiensis and Kudoa minithyrsites n. sp. from sweeper (Pempheris ypsilychnus). J Eukaryot Microbiol 50:215-219

Zhang JY, Yokoyama $\mathrm{H}$, Wang JG, Li AH and others (2010) Utilization of tissue habitats by Myxobolus wulii Landsberg \& Lom, 1991 in different carp hosts and disease resistance in allogynogenetic gibel carp: redescription of $M$. wulii from China and Japan. J Fish Dis 33:57-68

Zhao Y, Sun C, Kent ML, Deng JL, Whipps CM (2008) Description of a new species of Myxobolus (Myxozoa: Myxobolidae) based on morphological and molecular data. J Parasitol 94:737-742

Submitted: May 6, 2010; Accepted: October 7, 2010

Proofs received from author(s): January 21, 2011 